\title{
MAPPING THE BARRIERS OF RECEIVES AFFORDABLE MENSTRUAL HYGIENE PRODUCTS AND HEALTHCARE SERVICES AT THE RURAL SETTING OF BANGLADESH
}

\author{
Mohammad Shamsal Islam¹, AHG Quddus², Abbas Rahimi Foroushani ${ }^{3}$
}

\author{
${ }^{1}$ Senior Research Officer Dr. Ahmadur Rahman Research Centre University of Chittagong, Bangladesh. \\ ${ }^{2}$ Professor, Department of Sociology University of Chittagong, Bangladesh. \\ ${ }^{3}$ Professor, Department of Bio-Statistics and Epidemiology Tehran University of Medical Sciences, Islamic Republic \\ of Iran.
}

Correspondence: Mohammad Shamsal Islam, Email: msislam009@gmail.com

\begin{abstract}
Background: Menstrual hygiene health has paramount importance for the adolescents and women. The evidence based studies on menstrual hygiene management are very few and far less in rural setting of Bangladesh possibly for lack of interest in research and non-availability of the fund. Relatively menstrual hygiene do not lessen its importance as a subject as it one of the major cause of reproductive tract infections of adolescents and women.

Methods: The study had two sets of data: one set of data was collected from the community through in-depth interview and another was from Informal Group Discussions (IGD). Fisher (1993) formula was followed to determine the sample size. The data has been analyzed using SPSS. Descriptive and Qualitative statistical tools were performed to analyze the collected data. A total 500 adolescents and women were interviewed from four Upazilas.

Results: Mothers (78\%) were the reliable place for the sharing respondent's first menstrual experiences. About $95 \%$ respondents believed myths of the society about menstrual hygiene. About $78 \%$ respondents were used to old cloth. The collection of menstrual hygiene materials and dispose of used products were vexing problems in the rural setting. The major portion (63\%) has dreamed of having of menstrual hygiene product with good quality. The low cost of a product $(p<.001)$, expected healthcare services $(p<.040)$, awareness programs $(p<.001)$, social media $(p<.002)$ are useful tools to increase the user's having menstrual hygiene products and receiving services in the rural setting. Conclusions: The government should have scheme for adolescents and women at rural setting address to culture and beliefs, resources and practice. To improve the capacity of adolescents and women to practice quality and affordable sanitary napkin, it is recommended that to start sensitizing activities at community setting immediately.

Keywords: Menstrual hygiene, healthcare, rural, bangladesh.
\end{abstract}

\section{Introduction}

About $84 \%$ of the adolescents' populations live in the developing world and they are raising faster compare to other age groups (1). The women have passed about 6 years of their lifetime as a result of the menstrual cycle (2). The menstrual hygiene-related knowledge, attitude, and practices have paramount importance for the adolescents and women. Proper knowledge is required to manage the menstrual process, although the religious and cultural attitude of the society is strongly related to it (3). The unhygienic behavioral approach closely associated with myths of the society (4). The nonavailability of hygienic products and poor affordability are push factors to the users (5). The users of menstrual hygiene products are increasing day by day at urban setting, while the rural part has ignored due to user's poor KAP, low commercialization of quality products, weak health care system and bad lifestyle of the rural people (6). WHO declared the Universal health coverage secures health and well-being for women and girls everywhere from 2014. But in Bangladesh the menstrual hygiene health is neglected by health policy makers, political leaders and NGOs. The study goal was to identify the neglected areas of menstrual hygiene and it related health care services at the rural setting of Bangladesh.

\section{Methodology}

The qualitative and quantitative data were collected from the community by using a structured questionnaire format. Before collection of the data, three days training sessions were organized for the data collector. Ten female paramedics were included in the research team for collection of data. A total 500 adolescents and women were interviewed from four Upazilas. Relevant literature was reviewed to enhance our understanding of the issue in question. The questionnaires were pretest before 
finalization. Qualitative data were collected through Indepth Interviews (IIs) and Informal Group Discussions (IGD). Fisher (1993) formula was followed to determine the sample size (7). The data has been analyzed using SPSS. Descriptive results had been carried out using charts and graphs. Qualitative statistical tests such as Independent T-Test and Chi-squared had been used for the continuous response. Multiple regression models have been used to determine different covariates on the outcome variables. A meeting of the ethical committee was held on May 12, 2015, at Prottyashi research center. After a threat bear discussion on different ethical aspects of the study the committee unanimously approved the proposal.

\section{Results}

The mean age of married respondent was 27.6 years $( \pm 6.49)$, while unmarried was 16.7 years $( \pm 3.27)$. About $91.2 \%$ had enrolled in school. The average year of attending school was 11.43. Nearly half of the respondents (48\%) were housewives, $40 \%$ students, and $7 \%$ neither students nor housewives. Families are mostly nuclear (82\%) contrary to common belief of overwhelming prevalence of extended family in the rural areas. Monthly family income was 132.92 \$. Average menstruation age of respondents was 13.15 years. Respondents have shared their first menstrual experiences with their mothers (78\%), sister (15\%), aunt $(4.6 \%)$ and grandmother (2.5\%). Age, schooling, and sharing of knowledge significantly associated with the practice of menstrual hygiene $(X 2=17.54 \mathrm{df}=8$; Crama's $\mathrm{V}=.37 ; \mathrm{p}<.001)$.

Age does not seem to significantly associate with the use of menstrual hygiene materials. About $78 \%$ of the respondents were used to old cloth, $17.60 \%$ used to the sanitary napkin, $3.80 \%$ used new cloth and $0.60 \%$ familiar with cotton. Respondents who are used to old cloth, $61 \%$ of them used 3-4 pieces of cloth, $21 \%$ used 56 pieces and $17 \%$ used a $1-2$ piece of old cloth during menstruation. The alarming issue is that about $90 \%$ of the old cloth users had dried their used materials in an unhealthy way (Table 1).

Table 1. Percentage Distribution of materials used during menstrual hygiene by Age Category.

\begin{tabular}{|c|c|c|c|c|c|}
\hline $\begin{array}{c}\text { Materials used for } \\
\text { menstrual hygiene }\end{array}$ & $\begin{array}{c}\mathbf{1 2 - 1 5} \text { Years } \\
\mathbf{n}=\mathbf{1 1 1}\end{array}$ & $\begin{array}{c}\mathbf{1 6 - 2 0} \text { Years } \\
\mathbf{n}=\mathbf{1 4 6}\end{array}$ & $\begin{array}{c}\mathbf{2 1 - 2 7} \\
\text { Years } \\
\mathbf{n}=\mathbf{1 2 4}\end{array}$ & $\begin{array}{c}\mathbf{2 8 - 4 5} \text { Years } \\
\mathbf{n}=\mathbf{1 1 9}\end{array}$ & Total \\
\hline Sanitary Napkin & 03 & 06 & 5.20 & 3.40 & $\mathbf{1 7 . 6 0}$ \\
\hline Cotton & 0.0 & 0.0 & .20 & .40 & $\mathbf{0 . 6 0}$ \\
\hline Old cloth & 18.60 & 20.80 & 19.00 & 19.60 & $\mathbf{7 8 . 0 0}$ \\
\hline New cloth & .60 & 2.40 & .40 & .40 & $\mathbf{3 . 8 0}$ \\
\hline Total & $\mathbf{2 2 . 2 0}$ & $\mathbf{2 9 . 2 0}$ & $\mathbf{2 4 . 8 0}$ & $\mathbf{2 3 . 8 0}$ & $\mathbf{1 0 0} \%$ \\
\hline \multicolumn{5}{|r}{$\mathbf{x}^{\mathbf{2}}=\mathbf{1 9 . 7 3}, \mathbf{d f}=\mathbf{9}$, Crama's $\mathbf{V}=\mathbf{. 3 6} \mathbf{p}<\mathbf{0 . 0 6 0}$} \\
\end{tabular}

Its means that possibly the respondents haven't enough knowledge about hygiene menstrual materials or they can't afford its cost. About $63 \%$ of the respondents dream to have a good quality napkin. About $13.40 \%$ have no idea about its price and quality (Figure-01).

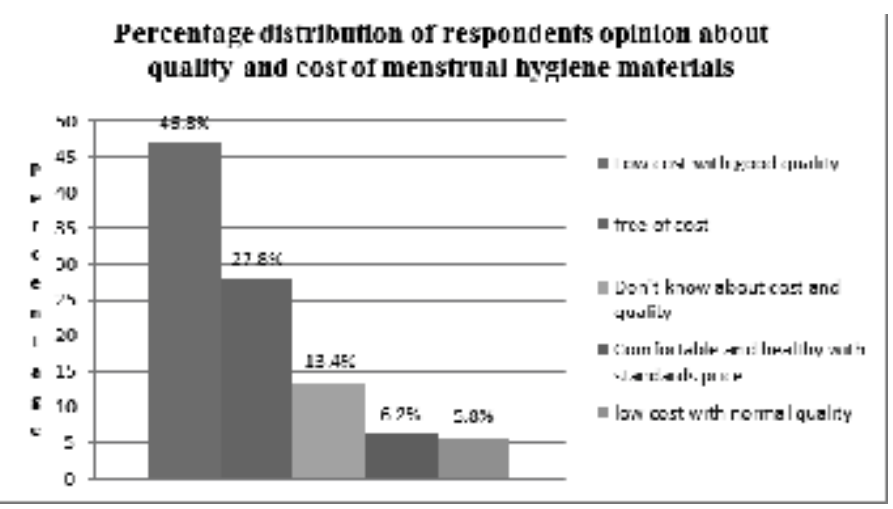

About $26 \%$ views (society) menstruation as harmful for the health, $13.6 \%$ consider menstruation as unholy, $17.2 \%$ not allowed going outside and 3.6\% consider menstruation as a curse (Figure-02).

Percentage Distribution of Vieus of People about Menstruation

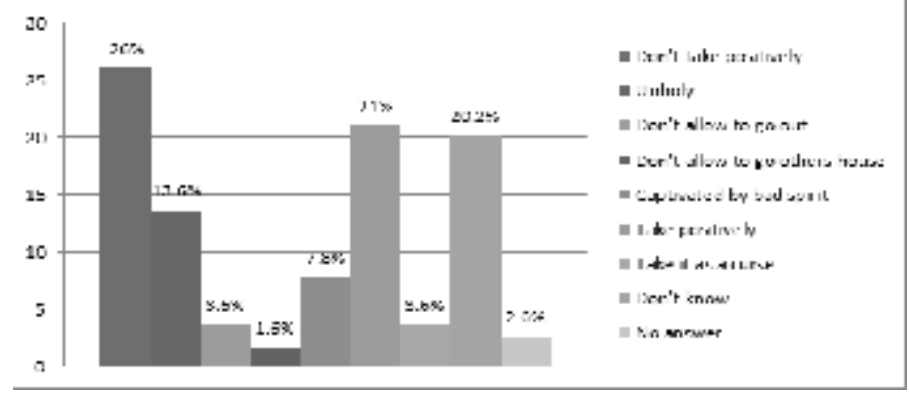

Most of the respondents (66.80\%) don't know about causes of menstruation (Table-02).

Table 2. Percentage Distribution of respondents' views about reasons of menstruation by education Category.

\begin{tabular}{|c|c|c|c|c|c|c|c|c|c|c|c|}
\hline $\begin{array}{c}\begin{array}{c}\text { Educational } \\
\text { level }\end{array} \\
\text { a }\end{array}$ & $\begin{array}{c}\text { Natural } \\
\mathrm{n}=27\end{array}$ & \begin{tabular}{|c|}
$\begin{array}{c}\text { One } \\
\text { kind of } \\
\text { disease } \\
\mathrm{n}=8\end{array}$ \\
\end{tabular} & $\begin{array}{l}\text { God } \\
\text { gifted } \\
\text { curse } \\
\mathrm{n}=43\end{array}$ & \begin{tabular}{|c|}
$\begin{array}{c}\text { For } \\
\text { gaining } \\
\text { weight } \\
\mathrm{n}=3\end{array}$ \\
$=3$
\end{tabular} & $\begin{array}{c}\text { For } \\
\text { having } \\
\text { pregnancy } \\
\text { n=11 }\end{array}$ & $\begin{array}{c}\text { Outflow of } \\
\text { contaminated } \\
\text { blood } \\
\mathbf{n}=10\end{array}$ & $\begin{array}{c}\text { Its } \\
\text { happens } \\
\text { when girls } \\
\text { turn into } \\
\text { adolescent } \\
\mathrm{n}=31\end{array}$ & $\begin{array}{c}\begin{array}{c}\text { Outflow } \\
\text { of } \\
\text { excessive } \\
\text { blood } \\
\mathbf{n}=29\end{array} \\
\end{array}$ & $\begin{array}{c}\text { No } \\
\text { answer } \\
\mathrm{n}=4\end{array}$ & $\begin{array}{l}\text { Don't } \\
\text { know } \\
\text { n=3344 }\end{array}$ & Total \\
\hline Primary & 0.60 & 0.20 & 0.0 & 0.60 & 0.80 & 0.80 & \begin{tabular}{l|l}
0.60 \\
\end{tabular} & $\begin{array}{l}0.0 \\
\end{array}$ & 0.20 & 13.60 & 17.60 \\
\hline Secondary & 2.80 & 0.80 & 7.20 & 0.40 & 1.60 & 0.80 & 4.60 & 4.00 & 0.40 & 42.0 & 64.60 \\
\hline $\begin{array}{l}\text { Higher } \\
\text { Secondary }\end{array}$ & 1.00 & 0.00 & 0.80 & 0.00 & 0.00 & 0.20 & 0.20 & 0.60 & 0.20 & 3.00 & 6.00 \\
\hline Degree & 0.60 & 0.00 & 0.20 & 0.20 & 0.40 & 0.20 & 0.00 & 0.00 & 0.00 & 0.40 & 2.00 \\
\hline Illiterate & 0.40 & 0.60 & 0.20 & 0.00 & 0.00 & 0.20 & 0.20 & 0.40 & 0.00 & 7.80 & 9.80 \\
\hline Total & 5.40 & 1.60 & 8.6 & 0.60 & 2.20 & 2.00 & 6.20 & 5.80 & 0.80 & 66.80 & 100.0 \\
\hline
\end{tabular}

About $73.03 \%$ of the respondents have faced problem for the collection of menstrual hygiene materials, while $40.44 \%$ have collected it by personally, $26.96 \%$ by mother, $22.47 \%$ by husband, $7.86 \%$ by the sister, and $2.24 \%$ by the brother. About $42.69 \%$ disposed of it opens space, $31.46 \%$ in the bathroom, $19.10 \%$ buried under the soil and $6.74 \%$ in public dustbin.

\section{Discussion}

Two sets of data were collected for the study. One collected by using structured questionnaire and another data were collected through In-depth Interviews (IIs) and Informal Group Discussions (IGD). Although both groups were adolescents and women, they have 
significantly differed in age structure. The mean age of married respondents was 27.6 years $( \pm 6.49)$, while unmarried was 16.7 years $( \pm 3.27)$. Average menstruation age of respondents was 13.15 years, while developed countries its 12.43 years (3). Sharing of knowledge about menstrual hygiene in adolescence stage may helpful to early identification of potential health concerns in adulthood. Our study we found that vast majority $(78 \%)$ have shared their menstrual experiences with their mothers. Education to mothers could be the better strategy to improve the reproductive health of adolescents. The important issue is that most of the respondents (78\%) were used to old cloth, while $90 \%$ old cloth users have dried their used cloth in an unhealthy way. The big barriers of the users are the collection of menstrual hygiene products and dispose of used materials. Only $5 \%$ have good knowledge about menstrual hygiene, remaining $95 \%$ believed myths of the society. A noticeable respondent $(88 \%)$ has mentioned about the high cost of a product and poor quality of the products $(63 \%)$. About $63 \%$ respondents have dreamed of having the low cost of the product with good quality. Registered village physicians5 receive patients from the community and they prescribe medicine for immediate relief of pain of reproductive health related problems. Our data we found that they often prescribe high antibiotic medicine which are extremely harmful for the innocent women health. A few women still go to traditional healers and Kabirajs. Young Informal Group discussants in the community think women have shunned superstitious beliefs to a great extent and do not take herbal or traditional medicines. The majority of the adolescents have the information about the places of services and hospitals but they are concerned about expenses. One of the observations of the researchers is that community people do not give much importance to reproductive health issues because it does not cause severe pain or difficulty in the health immediately. However, the village physicians have requested for day long workshop on how to deal with women reproductive health. We believe this suggestion is worth consideration. We have conducted 3 Informal Group Discussions (IGD): one with the cross section of people at a yard, one with the adolescents of a Madrasha, and one with the women and adolescents of villagers. According to women and adolescents views, menstruation is harmful to health, unholy, curse and something beneficial to their body. The participants mentioned that menstruation is occurred due to having weight, having pregnancy; it's exposed by having of outflow of contaminated blood. Adolescents have opined that hygiene products are not available and they can't afford it cost. Poor people can't afford the health care service and as a result, they go to quacks and kobirajs. The wage earners participants hold the view that due to financial constraints they go to quacks, religious healers, and herbal kabirajs. The discussion with the adolescents of a Madrasha was interesting.
They were very courteous and not allowed of our female interviewers to sit with them to discuss the issue. Their opinions were divided. Some opine that menstruation may be happened due to the variety of causes such as not eating enough green vegetable and essential elements, aging, accidents, and marry. Most of the participants were dissatisfied with the rural reproductive health care services. Adolescents and women around the country face tremendous challenges in meeting their reproductive health need, inadequate access to health information and services, as well as inequitable gender norms, can have serious implications on their health and welfare. The government and political leaders should have commitment to enough investment in universal access to Universal health coverage goals and strengthening health systems to scale up access to quality adolescents and women user friendly health services to achieve the UHC goals.

\section{Conclusion}

The government must have a new scheme towards menstrual hygiene products by a provision of subsidized sanitary napkins. Information, Education, and Communication (IEC) materials and information sessions could be effective tools to create awareness among users. Washable pads and low cost of the quality napkin can be marketing through Public Private Sector Partnership (PPP) program. An integrated awareness campaign cell could be developed in the rural health care setting to enhance the knowledge and remove existing myths about menstrual hygiene products and management. Social media can be involved in such programs. One menstrual hygiene products corner can be established at rural health care center. Regular yard meeting may be arranged for upgrading the menstrual hygiene knowledge against myths of the society.

\section{References}

1. Suzman R, Beard J. Global Health, and Aging. US Department of Health and Human Services and World Health Organization Joint Report. 2011; NIH Publication:11-7737.

2. Dickson S, Wood R . The Perceptions, Experiences and Meanings Rural girls ascribe to menarche - Implications for teacher/teacher training. Paper presented at the Australian Association for Research in Education Conference 1995.

3. Abdel HG, Karima B. Menstrual Hygiene among Adolescent School girls in Mansoura, Egypt. 2005; (05)26191-8.

4. The American College of Obstetricians and Gynecologists "Committee Opinion". Obstetrics \& Gynecology.2015; 126 (6):1328.

5. Herz B, Sperling GB (2004). What works in girls' education: evidence and policies from the developing world? New York Council on Foreign Relations,

6. Kayiggwa, P. Adolescents missing school during menstruation calls for sanitary pads. The New 
Times. 2017.

7. Fisher, K., Kuhn, N., Müller, H. J., Müller, J. P., and Pischel, M. Sophisticated and distributed: The transportation domain. In Proceedings of the Fifth European Workshop on Modelling Autonomous Agents and Multi-Agent Worlds. Neuchatel, Switzerland 1997. 